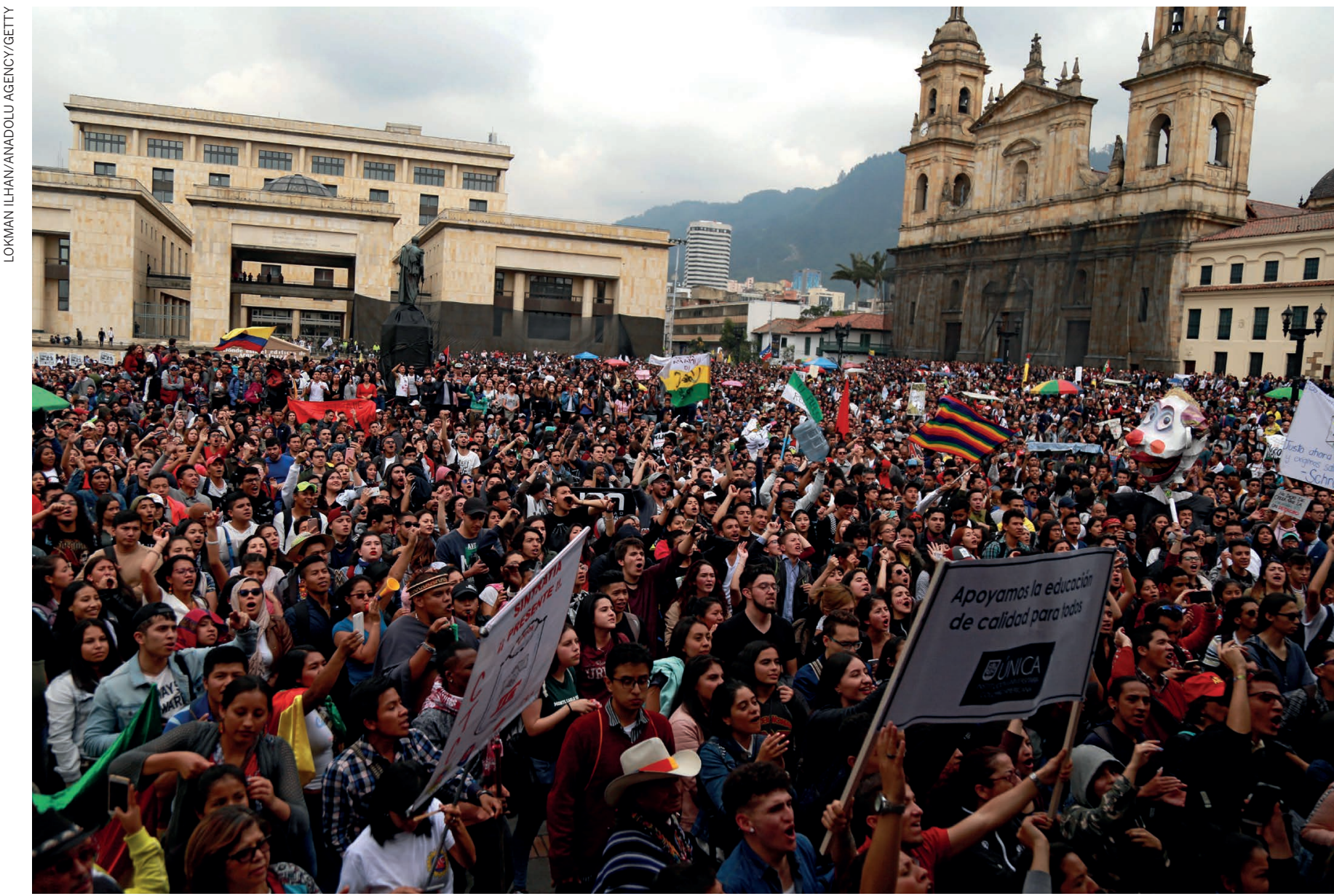

Students and academics march in Bogotá, Colombia, to demand more financial resources for higher education.

\title{
Science in Colombia on the cusp of change
}

\author{
The South American country faces deep-rooted problems, but \\ scientists are finding reasons to be hopeful.
}

\begin{abstract}
usana Fiorentino wants to unlock the secrets of Colombian folk medicine.

The immunologist, who directs the Immunology and Cellular Biology group at the Pontifical Xavierian University in Bogotá, Colombia's capital of 7 million people, is working with extracts from South America's anamú (Petiveria alliacea) and divi-divi plants, which she thinks can be used to treat breast cancer and leukaemia, thanks to their anti-tumour properties.
\end{abstract}

But while trying to get a phase I trial started with an extract from the divi-divi tree, Caesalpinia spinosa, she hit a snag. According to Colombia's drug-safety agency INVIMA, a molecule that identified the extract had to be chemically characterized before the plant could be used in a trial. There were no Colombian laboratories capable of doing the job, so she found labs in China and the United States that could do the work if she posted samples to them. But the request to re-import the fully characterized molecule, to be used in a Colombia-based trial, was denied with no clear reason, says Fiorentino.

The only way to get that potential medicine approved would have been to extract, characterize, synthesize and manufacture it in Colombia, in a laboratory that had not yet been built. Fiorentino had to go back to the plant and isolate another molecule to use as an identifier. She eventually found a laboratory at Colombia's University of Antioquia that could characterize it, instead of having to look abroad for help.

"It was absolutely ridiculous," explains Fiorentino. "Getting that clinical protocol was a path over waterfalls filled with rocks and thorns."

Fiorentino's experience with Colombia's scientific bureaucracy is all too common for researchers in a country emerging from a half-century of civil war. With a peace accord between Marxist rebels and the government signed in November 2016, the country is turning its attention to building the pillars needed to support a strong economy.

Colombia, the only country in South 
Q.8A

\section{Species seeker}

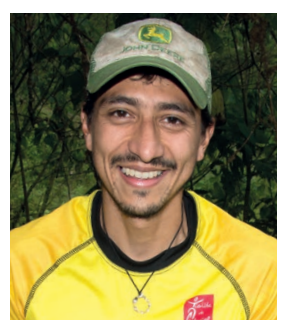

During his PhD

at the University

of Minnesota in

Minneapolis, Juan

Fernando Díaz

Nieto was part

of an expedition

that trekked

across the tropics

of South America and discovered a new

species of mouse oppossum (R. S. Voss

et al. Am. Mus Novit. 3778, 1-27; 2013).

He's since returned to his native Colombia,

where he is a professor of biology at EAFIT University in Medellín.

\section{What do you study?}

I work with marsupials, rodents and bats. I've always been interested in fieldwork - being able to go to unexplored regions that have a high potential for diversity. I also work in museums and use genetic techniques to investigate diversity.

What's it like to do fieldwork in Colombia? For decades Colombia had zones that were too dangerous to go into. The 2016 peace accord with the FARC, which ended the long civil war here, helped give access to large regions of the country. It's still complicated: to access these areas, one must be careful, work out the logistics and sometimes ask permission - and not just of the government. Many areas have been taken over by other armed groups.

Tell us about a project you recently led. In July, I and colleagues led a biodiversity project in the Anorí region in Colombia, which is United Nations-backed and involved ex-combatants from the FARC. They weren't serving as guides but as co-investigators. We planned the project with them. After the fieldwork they came to our laboratories in Medellín, working alongside us.

\section{What's the future for science in Colombia?} There's a lot of altruism among researchers here. One person might go into a difficult zone and end up giving the world access to a valuable sample. There are lots of social issues in our country that we have to face. But we are willing - our passion will

guide us.

\section{INTERVIEW BY ALESZU BAJAK}

This interview has been edited for length and clarity.
- America to be bordered by both the Caribbean Sea and the Pacific Ocean, is a mosaic of ecosystems, including mountain ranges, deep jungle, rugged coasts and expansive savannah. It is the second most biodiverse nation in the world (behind neighbouring Brazil) and, thanks in part to this natural laboratory, the country of 49 million people has dozens of universities and institutes working on home-grown science, ranging from the International Center for Tropical Agriculture in Cauca Valley to the natural and physical science laboratories of Bogotás largest universities (the city has more than 100 tertiary education institutes).

But the key question being asked by Colombian scientists is whether science will find support in the country's post-war economy. For years, their outlook has been pessimistic in the face of strained budgets, meagre resources and red tape that stymie the scientific process, explains Andrew Crawford, a US biologist who, over the course of nine years at Bogotás Los Andes University, says he has developed a sense of the possibilities and challenges of doing science in Colombia.

A reagent order that could be delivered in a day in the United States or Europe, for example, can take three months in Colombia, says Fiorentino. Monoclonal antibodies, she says, have sat for weeks without refrigeration in customs, useless by the time they reached the lab.

"If we do not improve these administrative problems," Fiorentino stresses, "Colombia will never, never be competitive."

\section{MEAGRE SUPPORT}

Many of these problems, researchers point out, are rooted in the government's low financial support for science. Colombia currently invests only $0.67 \%$ of its gross domestic product in science and technology, compared with $2.8 \%$ in the United States.

Despite this, the country produces on average more than 200 high-quality scientific studies a year on everything from physics to Earth and environmental sciences to the life sciences, according to the Nature Index, which tracks publication in high-quality scientific journals. Recent Colombian papers have made advances in research on dark matter, urban lizards and forest fragmentation. But that output trails behind that of other countries in the region, such as Brazil and Argentina, which until recently invested a lot more in research. Colombia's spending was only onefifth of Argentina's in 2015, for example. Today, however, uncertain political and economic conditions in those two countries might offer Colombia a chance to catch up.

Last year, 13 Nobel laureates from around the world wrote to then-president Juan Manuel Santos, urging him to raise the government's investment. "The Colombian budget for science and technology for 2018 continues to be extremely low," they wrote, adding: "The consequences will be devastating and irreversible, because science and education are long-term efforts that must be supported consistently."

The letter summarized the growing disenchantment among Colombian researchers about the future of science there. As Enrique Forero, president of the Colombian Academy of Exact, Physical and Natural Sciences in Bogotá, points out, federal funding is decreasing further. "Support from the government is not very acceptable. It's very, very, very low and it seems to be going down every year," he says.

\section{BRAIN DRAIN}

Catalina Pimiento is one Colombian scientist who left and never returned. After graduating from the Pontifical Xavierian University with a degree in biology, she moved first to Mexico, then Panama, the United States, Switzerland, Germany and now Wales, where she has a postdoctoral fellowship at the University of Swansea, investigating mass extinctions like the one that took out the giant shark Carcharocles megalodon. As much as it pains her, she won't return to her country of birth.

"Because of my experiences and the career opportunities I've had abroad, I decided to have nothing to do with Colombia," she says. "Colombia does not invest in science. It's that simple."

That's not to say that researchers in Colombia can't make a living - or new discoveries - in the current climate. Juan Fernando Díaz Nieto, a biologist at EAFIT University in Medellín, has a successful career identifying new opossums, rodents and bats in the country's hinterlands that had for decades been inaccessible because of the violence and threat of kidnapping associated with the civil war (see 'Species seeker').

"The peace accord helped with access to large regions of the country," says Díaz Nieto, who recently discovered two new marsupial species along the river of Colombia's Magdalena basin, in the northwest of the country. "We described two new species of mouse opposum that are endemic to Colombia, which we found on either side of the Magdalena River," he explains.

Díaz Nieto, who gained his $\mathrm{PhD}$ at the University of Minnesota in Minneapolis, says he was able to make the discoveries because "in lieu of large budgets, we relied on the cooperation of colleagues at other Colombian institutions and cobbled together many small grants from the National Science Foundation, the University of Minnesota and the American Society of Mammalogists."

\section{SCIENCE TAX}

The Colombian government is trying to get better at funding science, however. A law passed in 2012 diverted $10 \%$ of royalties from natural-resource extraction into a science and technology fund that was allocated across Colombia's 32 government departments. The initiative was designed to help stimulate science by sponsoring research projects and 
investing in university research centres in a geographically equitable manner.

Some of it worked. Infectious-disease research was funded along Colombia's Caribbean coast. In Bogotá, Fiorentino received more than US\$1 million towards her biopharmaceutical research. And 300 kilometres to the west, a new scientific research centre was built at the University of Caldas in Manizales.

But much of the scheme backfired, in part because of the bureaucracy the new system required. "It was literally impossible to spend the money because of the logistics and paperwork," explains Crawford. "The whole thing was designed upside down."

The nail in the coffin, explains Moises Wasserman, former director of the National University of Colombia in Bogotá, was that approval of these scientific projects was placed in the hands of local politicians instead of scientific review boards. "It was very poorly planned," he says. "The decisions and a large part of the execution were left to very politicized entities who have relatively short tenures - governors with four-year terms."

Under the auspices of provincial governors, millions went to agriculture, aquaculture, energy and infrastructure projects that could hardly be characterized as science, according to an analysis by investigative reporters at La Silla Vacía, a Colombian political news website. The convoluted application process ultimately slowed the disbursement down so much that two of every five pesos in the fund went unspent, the investigation claimed.

Nature approached the Colombian government for comment, but did not hear back before this story went to press.

\section{LOOKING AHEAD}

But many Colombian scientists say there's light at the end of the tunnel. Last June, the government proposed a bill that will create a Ministry of Science, Technology and Innovation.
The bill is designed to ensure that science has a voice at the highest level of government, according to Iván Darío Agudelo, a senator and the bill's sponsor.

And last July, a month before now-president Iván Duque Márquez was sworn in, he met Forero and 30 other Colombian scientists at the National Academy of Sciences in Bogotá to discuss the future of science in Colombia. By the end of the meeting Duque had pledged, on Twitter, to restructure how science was administered in the country.

"Things seem to be changing," says Forero. "We hadn't had a president in the academy headquarters for 200 years. Or a presidentelect. We're not completely invisible any more. People know that we exist."

Some Colombian researchers aren't waiting for the government to increase its investment in science or build a new ministry. Carlos Guarnizo, an ecologist at the Los Andes University, says there are things that individual scientists can do to grow science in the country. Guarnizo and his colleagues started Ciencia Sumercé, a science-communication initiative that includes live events at a restaurant in central Bogotá and regularly draws crowds of hundreds, eager to learn about artificial intelligence, climate change or urban ecology.

One priority is keeping the panellists as diverse as he can find. "We want to show that researchers are not just bald old men but ordinary people, of any age, of any gender," says Guarnizo, who hopes his events and accompanying social media activity will draw young people to science.

In that way, he hopes to grow a new generation of science-savvy Colombians. "That could have untold consequences for our country." -

Aleszu Bajak teaches journalism at Northeastern University in Boston, Massachusetts. He grew up in Bogotá.

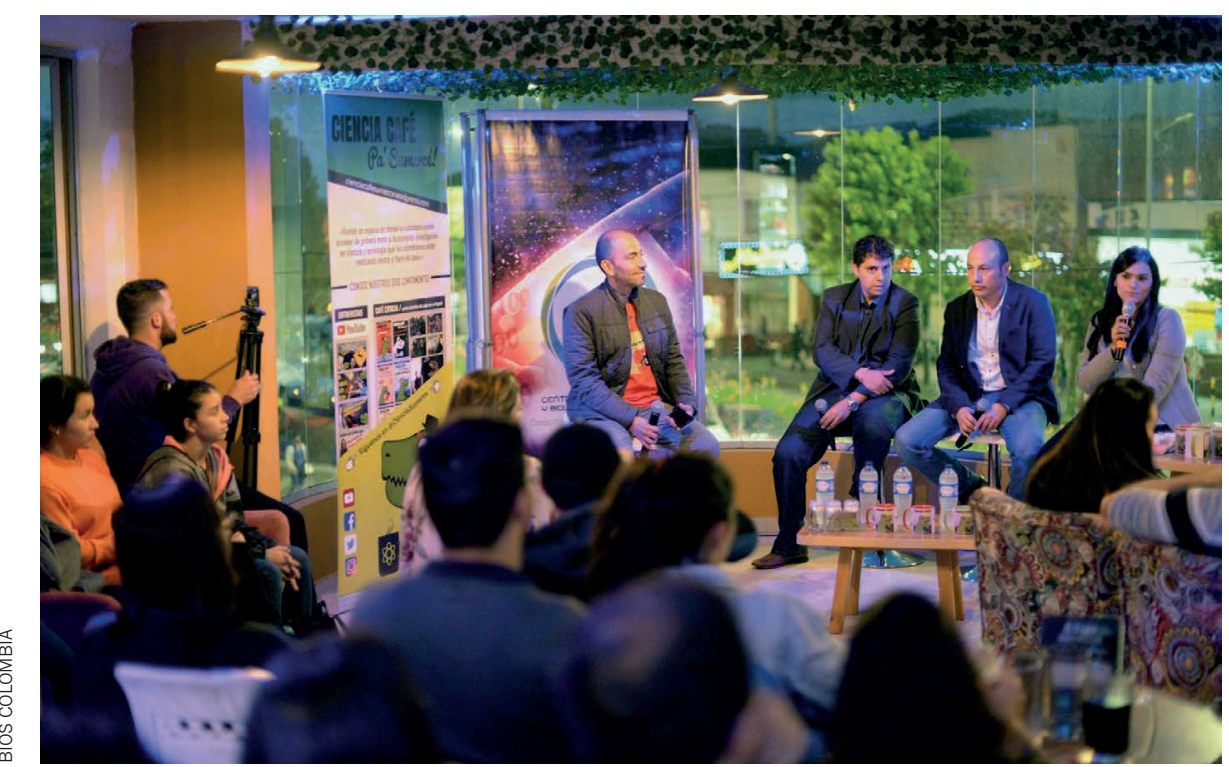

A science café in Manizales, Colombia, discusses how biotechnology might help local coffee growers. 


\section{CORRECTION}

The Spotlight article 'Science in Colombia on the cusp of change' (Nature $\mathbf{5 6 2}$,

S109-S111;2018) erroneously stated that Colombia is bordered by the Atlantic Ocean. In fact, it is the Pacific Ocean. 